\title{
From infra-humanization to discrimination: The mediation of symbolic threat needs egalitarian norms ${ }^{\text {is }}$
}

\author{
Cícero Pereira $^{\mathrm{a}, \mathrm{b}, *}$, Jorge Vala ${ }^{\mathrm{a}}$, Jacques Philippe Leyens ${ }^{\mathrm{c}}$ \\ a Institute of Social Science, University of Lisbon, Portugal \\ ${ }^{\mathrm{b}}$ Catholic University of Goiás, Brazil \\ ${ }^{\mathrm{c}}$ Catholic University of Louvain, Louvain-la-Neuve, Belgium
}

\section{A R T I C L E I N F O}

\section{Article history:}

Received 26 March 2008

Revised 14 October 2008

Available online 26 October 2008

\section{Keywords:}

Infra-humanization

Discrimination

Symbolic threat

Norms

\begin{abstract}
A B S T R A C T
This set of studies tests the link between infra-humanization, symbolic threat, and discrimination within normative contexts. In two experiments, manipulating the degree of humanity of a disliked outgroup has an effect upon the discrimination towards it. The infra-humanized outgroup is more discriminated than the humanized one. Also, the perception of symbolic threat plays the role of a justifying factor for discrimination, and mediates the relationship between degrees of humanity and discrimination. Study 2 further shows that this mediation occurs only when an egalitarian norm is activated, and not when meritocracy is made salient. The discussion focuses on factors likely to prevent infra-humanization of outgroups. It also considers how norms may change the role of threat.
\end{abstract}

(c) 2008 Elsevier Inc. All rights reserved.
Recent research has taken into consideration the degree of humanity attributed to groups. Most ingroup members are ethnocentric and believe that their group is fully human whereas they consider that many outgroups are less human. This phenomenon has been called infra-humanization (see Leyens, Demoulin, Vaes, Gaunt, \& Paladino, 2007; Leyens et al., 2000). It does not mean that outgroups are denied any humanity, but refers to the way in which outgroup members are deprived of complete humanness by attributing them fewer uniquely human characteristics, such as secondary emotions (i.e., love, contempt) than to ingroup members (for reviews, see Demoulin et al., 2004; Leyens et al., 2007).

Almost by definition, if a group is infra-humanized, it will be discriminated against more strongly than a humanized one. The present set of studies is the first to investigate the discriminatory consequences of experimentally manipulated infra-humanization, and to look at the role of symbolic threat into the association between infra-humanization and discrimination. We expect infrahumanization to elicit symbolic threat, but this threat may signal a danger as well as a justification for ill-intentioned behaviors. It is a danger when it could jeopardize the identity and values of the ingroup. It is a justification when it serves to legitimize differences and discrimination. To distinguish the two roles, normative

\footnotetext{
This work was partially supported by a CAPES Grant, Ministério da Educação, Brasil, awarded to Cícero Pereira and by a Grant of the Fundação para a Ciência e a Tecnologia awarded to Jorge Vala.

* Corresponding author. Address: Institute of Social Science, University of Lisbon, Av. Professor Aníbal de Bettencourt, 91600-189 Lisbon, Portugal.

E-mail addresses: cicero.pereira@ics.ul.pt (C. Pereira), jorge.vala@ics.ul.pt (J. Vala), jacques-philippe.leyens@uclouvain.be (J.-P. Leyens).
}

contexts (i.e., egalitarian and meritocratic) will be manipulated. Whether the context is favorable or not to discrimination, we predict stronger discrimination and higher perceived threat for the infra-humanized group relatively to the humanized one. However, the normative context should affect the role of threat. To discriminate in an egalitarian environment asks for a justification, and symbolic threat mediates the link between infra-humanization and discrimination. By contrast, if the context accepts discrimination, there is no need for justification and threat constitutes the sign of danger without links to discrimination.

\section{Infra-humanization}

To explain variations between groups, people tend to believe that they are characterized by essential differences (Haslam, 2006). In other words, people believe that groups are what they are by substance and not by contingencies, and people also believe that similarities, or differences, go behind the surface. The most general essence is the human one, and, because groups are ethnocentric, it means that their group is perceived as more human, and less bestial, than outgroups (Leyens et al., 2000, 2003). A series of studies have shown that ingroup members associate "uniquely human" emotions (e.g., affection, contempt) faster with their ingroup than with outgroups (e.g., Boccato, Cortes, Demoulin, \& Leyens, 2007; Paladino et al., 2002). People also attribute more uniquely human emotions to the ingroup than to outgroups (e.g., Cortes, Demoulin, RodriguezTorres, Rodriguez-Perez, \& Leyens, 2005; Leyens et al., 2001).

Previous correlational research has shown a link between infrahumanization and negative outcomes. For instance, infra-human- 
ization is related to lack of forgiveness between conflicting groups such as Catholic and Protestant Northern Irish (Tam et al., 2007). In addition, infra-humanization correlated with the lack of intentions to help victims of Hurricane Katrina in the USA (Cuddy, Rock, \& Norton, 2007). Although these studies have shown a relationship between infra-humanization and negative outcomes, the correlational design raises questions about the causal direction of the findings. Vaes, Paladino, Castelli, Leyens, and Giovanazzi (2003) used experimental designs, but they did it with specific aims in mind. They showed that the spontaneous expression of secondary emotions by ingroup and outgroup members caused a general tendency to be friendly with, to take as a model, and to approach ingroup members as compared with outgroup members who were plainly rejected. Nothing of this sort happens with primary emotions (e.g., happiness, anger) because they belong to everybody including animals.

\section{How normative contexts moderate the role of symbolic threat?}

As proposed by theories of justification-suppression (Crandall \& Eshleman, 2003), of aversive racism (Dovidio \& Gaertner, 1986), and of social dominance (Sidanius \& Pratto, 1999), the expression or non-expression of discrimination often depends on justifications that vary according to specific contexts. Contexts carry with them social norms that indicate to group members what they should or should not do, prescribing appropriate behaviors as well as actions that should be repressed (Cialdini, Kallgren, \& Reno, 1991; Cialdini \& Trost, 1998)

Pettigrew (1958) was probably one of the first researchers to insist upon the role of surrounding norms in the expression of discrimination. If norms are associated with discrimination, expressions of discrimination should not present a problem for people, and discrimination does not need to be justified. By contrast, if discrimination against minority groups persists even under the pressure of a normative standard that condemns discrimination, it will elicit tension. One way to get rid of this tension is to possess a justification for discrimination, such as experiencing a feeling of symbolic threat.

Several researchers have already measured symbolic threat in relation to infra-humanization in correlational studies. Viki, Gratien, Eller, Alys, \& Pina (submitted for publication) found that infra-humanization of asylum-seeking immigrants correlated with symbolic threat. Zimmermann, Doosje, Zebel, and Viki (submitted for publication) also obtained a correlation between infra-humanization of terrorists and symbolic threat. Moreover, Viki, Zimmermann, \& Ballantyne (2008) found that symbolic threat played the role of mediator between religious origins (Christian vs. Muslim) and the ill-treatment and exclusion of Muslims. It should be noted that none of these studies found a relation with realistic threat (Stephan \& Stephan, 2000). According to Viki, Gratien et al. (submitted for publication) and Viki, Zimmermann et al. (submitted for publication), this finding is because symbolic threat refers to concerns about values, and culture. These are some of the factors that laypeople perceive as distinguishing humans from animals (Demoulin et al., 2004). If culture and values are some the factors that distinguish humans from animals and the immigrant group is viewed negatively on these aspects, then it is possible that asylum seekers may be viewed as less human in comparison to the ingroup; especially by those individuals who score high (vs. low) on perceived symbolic group threat. Thus, threat played the role of justification in this context.

For the same reason of justification, we predicted that threat would mediate group membership and discrimination. Indeed, our population of a liberal college is probably composed of aversive racists (Dovidio \& Gaertner, 1986) who only discriminate when some apparent non-racist justification is available (for a metaanalysis, see Saucier, Miller, \& Doucet, 2005). Ill-intentioned behaviors do not occur in a vacuum but in a social context in which norms may vary. Not all norms are in line with aversive racism. The work of Katz and Hass (1988) is ideal to select values that counter anti-discrimination norm or that allows discrimination. According to these authors, egalitarianism (e.g., equality and social justice) is the basis of norms for anti-discrimination (Moskowitz, Gollwitzer, Wasel, \& Schaal, 1999; Moskowitz, Salomon, \& Taylor, 2000). By contrast, meritocratic norms (e.g., effort, competition, merit, and hierarchy) are associated with all kinds of discrimination (Biernat, Vescio, \& Theno, 1996; Vala, Lima, \& Lopes, 2004). To sum up, these investigations show that egalitarianism supports an anti-discrimination norm and that meritocracy weakens this norm and facilitates discrimination.

In this research, we go further in the analysis of the relationship between infra-humanization, contextual norms, and discrimination, and we hypothesize that different psychological processes may occur, depending on the salience of the type of norm. When meritocracy is salient, people do not need justifications for their discriminatory behavior. In other words, when the norm of the context is permissive, infra-humanization leads to threat and discrimination, but threat does not mediate the link between infra-humanization and discrimination. By contrast, when egalitarianism is salient, people do need justifications. In this case, infra-humanization leads to ill-intentioned behavior that has to be justified by symbolic threat, which plays the role of mediator.

\section{Overview of the studies}

In Study 1, Portuguese participants had to rate the extent to which they perceived Turkey, a disliked outgroup, as a threat to European identity (measure of symbolic threat), and also the extent to which they were opposed to the admission of Turkey to the European Union (measure of discrimination). The degree of humanity of the outgroup was manipulated by scientific feedback concerning the frequency of secondary emotions in the Turkish vocabulary (equal to the mean of the European Union countries, much less secondary emotions, and no information about the emotions). In Study 2, the same dependent variables were used and participants had to take a position regarding a humanized or infra-humanized Turkey after having been primed by meritocratic or egalitarian norms.

\section{Study 1}

In 2004, the European Parliament approved negotiations for the entry of Turkey in the EU. These negotiations are still in progress, but differences of opinion persist both among representatives of governments and opinion makers. As far as public opinion is concerned, only $28 \%$ of the Europeans, and $40 \%$ of the Portuguese, are in favor of accepting Turkey into the EU (Eurobarometer, 2006). The main arguments for opposing Turkey's adhesion involve the affirmation of deep cultural differences between Turkey and current members of the EU, and come from a long history of cultural, religious, and political conflicts. From this point of view, Turkey is a threat to "Western Judeo-Christian civilization".

Based on the classic paradigm of infra-humanization (Leyens et al., 2001), we experimentally manipulated the degree of humanity of the Turkish people. While control participants did not receive any information concerning Turkish emotional vocabulary, participants in the humanized condition learned from a scientific source that secondary emotions were used in Turkey more than primary ones and to the same extent than European countries. In the infra-humanization condition, primary emotions were dominant 
and secondary ones were comparatively deficient. We used only emotions because it is at the core of infra-humanization. We did not add other areas in which countries could potentially have been viewed as similar or dissimilar. Indeed, we simply wanted to manipulate infra-humanization but not to create a common identity (Gaertner \& Dovidio, 2000). We verified this assumption by controlling for perceptions of similarity-differences between Turkey and the EU.

It was hypothesized that the manipulation of infra-humanization would affect perception of symbolic threat and opposition to Turkey. More threat and more opposition were expected in the infra-humanized condition than in the humanized one. Moreover, and importantly, it was hypothesized that perception of symbolic threat would mediate the link between infra-humanization and opposition.

\section{Method}

\section{Participants and design}

One hundred and five university students (75\% female) of the Lisbon University Institute took part in this study. Participants were randomly distributed in one of three experimental conditions: infra-humanization $(n=35)$; control $(n=35)$; humanization $(n=35)$.

\section{Procedure and manipulation}

The study involved two phases carried out in classrooms with two researchers. In the first phase, one of the researchers manipulated humanity. In the second phase, the second researcher distributed a questionnaire to measure the perception of symbolic threat and participants' opposition to the Turkish entrance in the EU.

The first phase began with a first researcher asking participants to read an article supposedly published in a high-circulation newspaper, and to answer a small questionnaire on what they had just been reading. The alleged objective of the study was to find out what people think of how newspapers handle the dissemination of scientific data. The researcher then presented a photocopy of an article supposedly published in the on-line version of a wellknown weekly newspaper. In order not to arouse any suspicion about the article, the graphics (i.e., layout, font, spacing, links, advertisements, etc.) typically published in this newspaper were reproduced. The content of the article manipulated different representations of how Turkish people express emotions. Depending on the experimental condition, the text was written so as to activate an infra-humanized representation of Turks, a more humanized one, or none at all (control condition). In the humanization condition, the text contained a summary of research carried out in the University of Istanbul and published in a scientific journal. It stated that scientists had discovered that both Turkish and European Community people express secondary emotions (sentimentos in Portuguese) more readily than primary (emoções in Portuguese) ones. A bar chart illustrated the equivalence. In the infra-humanization condition, the article supposedly showed that Turks express primary emotions (e.g., fear, joy) more readily than secondary ones (e.g., love, shame), whereas people from European Union countries tend to express secondary emotions more readily than Turks. A bar chart again illustrated the difference in the use of primary and secondary emotions. In the control condition, the text dealt with the relation between age and learning of a new language. In this condition, no association between the expression of primary and secondary emotions and Turkish people was activated. ${ }^{1}$

\footnotetext{
1 The text in Portuguese is available from the authors.
}

After reading the article, participants answered a questionnaire containing measures concerning several aspects of the article and the differential association of primary and secondary emotions. In the control condition, the questionnaire did not contain questions about emotions in order to avoid activating infra-humanization or humanization of Turkish people. Finally, the researcher thanked the participants and left the room.

Immediately thereafter, a second researcher started the second phase with the same participants. He told them that he would like their collaboration in a study on the admission of new countries to the European Union. Participants' task was to respond to a questionnaire on the possible entrance of Croatia, Romania, and Turkey into the EU. The inclusion of Croatia and Romania was merely for the purpose of preventing participants from suspecting there was a link between the two phases of the procedure. The questionnaire contained a set of additional items measuring socio-demographic data, perception of similarity-dissimilarity, and perceived symbolic threat. After answering the questionnaire, participants were thanked and debriefed.

\section{Perception of similarity-difference}

This factor was measured through a single item: "Regarding all aspects, to what extent are each of these countries different or similar to the current countries of the European Union?" The participants indicated their perception of similarity/difference between each country (Croatia, Romania, and Turkey) and the current countries of EU on a 7-point scale ( 1 = very similar; 7 = very different).

\section{Symbolic threat}

Perception of threat for each of the three countries was measured by the following four items: "To what extent will the admission of any of these countries to the European Union enhance or undermine core European values?”; “...enhance or undermine the customs of the European Union?”; “...enhance or undermine European identity? “...undermine or strengthen the unity of European culture?" For each question the answer scale varied from 1 (will enhance/strengthen a lot) to 7 (will undermine a lot).

\section{Discrimination}

Opposition to each of the three countries was measured by the following 7-point scales (from 1 = completely in favor; totally willing; very likely to 7 = completely against; totally unwilling; not at all likely): "Please indicate whether you would be willing to be part of a group supporting the admission of each of the countries listed below to the European Union”; “. . .to collect signatures in favor of each of these countries joining the European Union"; “... to send a collective mobile phone message to the European Commission in support of each of these countries joining the European Union".

\section{Pre-test of texts}

The texts used for the manipulation were pre-tested. We assessed their equivalence regarding the perception of comprehensibility, quality of the text presentation, example of scientific dissemination, and inherent interest. A MANOVA with the manipulation of humanity (infra-humanization vs. control vs. humanization) as a between participants factor was carried out. The multivariate manipulation effect was not significant $F(8,200)=1.24$, ns. Furthermore, none of the univariate effects were significant.

\section{Pre-test of emotional words}

Twenty-eight emotional words (eight used as training examples; 20 used in the manipulation check) were pre-tested for their degree of humanity, their valence and the desirability of their expression (e.g., Vaes et al., 2003). As expected, the only main ef- 
fect was found for humanity, $F(1,24)=222.67, p<.001, \eta^{2}=.90$. Moreover, none of the effects were moderated by valence.

\section{Results}

\section{Manipulation check of infra-humanization}

The 20 emotions were presented in a list to participants in the humanization and infra-humanization conditions. They contained 10 primary emotions (five positive and five negative) and $10 \mathrm{sec}-$ ondary ones (five positive and five negative). Participants had to indicate (on a scale from $1=$ not at all likely, to $7=$ very likely) to what extent they thought Turkish people would express each of the emotions. A 2 (Humanity manipulation: infra-humanization vs. humanization) $\times 2$ (Type of emotions: primary vs. secondary emotions) $\times 2$ (Valence: positive vs. negative) mixed ANOVA was calculated on the scores of expression of emotions. It revealed only a significant interaction between humanity manipulation and type of emotions, $F(1,68)=16.22, p<.001, \eta^{2}=.19$. As expected, Turks in the infra-humanization condition were more likely to express primary emotions $(M=4.53, S D=0.71)$ than secondary ones $(M=4.34, S D=0.82), F(1,68)=6.98, p<.01$. In the humanization condition, primary emotions $(M=4.40, S D=0.91)$ were expressed less than secondary emotions $(M=4.61, S D=0.78), F(1,68)=9.33$, $p<.01$. Conforming to the infra-humanization model, valence did not play any role. Hence, one may conclude that the manipulation activated different levels of humanity among Turkish people.

\section{Perception of similarity-difference}

The scores on perception of similarity-difference were examined using a 3 (Manipulation of humanity: humanization vs. control vs. infra-humanization) $\times 3$ (Countries: Croatia vs. Romania vs. Turkey) ANOVA. The results show that the main effect of manipulation is not significant, $F(2,102)=1.67$, ns. The main effect of country is significant, $F(2,204)=16.69, p<.001, \eta^{2}=.20$. Simple effects show that Turkey $(M=5.09, S D=0.93)$ is perceived as more different from the EU than Croatia $(M=4.59, S D=0.86)$, $F(1,102)=23.55, \quad p<.001, \quad \eta^{2}=.19, \quad$ and Romania $(M=4.79$, $S D=0.83), F(1,102)=10.29, p<.01, \eta^{2}=.09$. Romania is perceived as more different than Croatia, $F(1,102)=11.66, p<.001, \eta^{2}=.10$. Importantly, the interaction is not significant, $F<1, n s$.

\section{Symbolic threat}

Factorial analyses (using the principal axis factoring method) were carried out on the answers to items of the symbolic threat to verify the factorial validity of these measures for each country. In each analysis, only one factor was extracted explaining $51 \%$ of the variance for Croatia (eigenvalue $=2.07$; loadings varying from .66 to .76 ), $52 \%$ for Romania (eigenvalue $=2.13$; loadings varying from .64 to .80), and $52 \%$ of the variance for Turkey (eigenvalue $=2.14$; loadings varying from .69 to .76 ). The composite measures of symbolic threat perception were reliable for each country: Croatia $(\alpha=.81)$; Romania $(\alpha=.82)$; Turkey $(\alpha=.82)$. ANOVA's results showed that the composite scores of symbolic threat induced by Croatia, $F(2,102)=1.99$, ns. $\eta^{2}=.04$, and by Romania, $F(2,102)=1.88$, ns. $\eta^{2}=.04$, were not influenced by the humanity manipulation of Turkey. By contrast, and as seen later in the mediation section, the symbolic threat scores for Turkey are influenced.

\section{Discrimination}

Factorial analyses on the discrimination items extracted only one factor for each country, explaining $51 \%$ of the variance for Croatia (eigenvalue $=2.03$; loadings $=.44-.86$ ), $59 \%$ for Romania (eigenvalue $=2.37$; loadings $=.51-.91$ ), and $51 \%$ for Turkey (eigenvalue $=2.05$; loadings $=.35-.90$ ). The composite measures were reliable $(\alpha=.78, \alpha=.73$, and $\alpha=.77$ for Croatia, Romania and Turkey, respectively). ANOVA's results on composite scores showed no effect of Turkish humanity upon discrimination against Croatia, $F(2,102)=1.61, n s . \eta^{2}=.03$, and Romania, $F(2,102)=2.11, n s$. $\eta^{2}=.04$. It was not the case for Turkey (see below).

\section{Mediation analysis}

To carry out the mediation analysis, a multiple regression approach was used (see Baron \& Kenny, 1986). The experimental conditions were coded in order to represent a linear (i.e., infrahumanization $=1$; control $=0$; humanization $=-1$ ) and a quadratic (i.e., infra-humanization $=-1 ; \quad$ control $=2 ;$ humanization $=-1$ ) relationship between the experimental conditions and the different levels of humanity of Turks.

In the first step of the mediation analysis, results showed that the humanity manipulation significantly influenced discrimination against Turkey, $R=.26, R_{\text {Adjusted }}^{2} .05, \quad F(2,102)=3.83$, $p<.05$. Moreover, regression analyses indicated that the only significant predictor was the linear contrast $(b=.28, S E=.11$, $t=2.65, p<.01$ ). This finding means that the opposition to Turkey is significantly smaller in the humanized condition $(M=3.89, S D=0.71)$ than in the infra-humanized one, which has a mean $(M=4.45, S D=0.75)$ close to the one of the control condition $(M=4.32, S D=1.13){ }^{2}$ In the second step, the degree of humanity significantly influenced the perception of symbolic threat, $R=.30, R_{\text {Adjusted }}^{2}=.08, F(2,102)=5.44, p<.01$, so that threat perception was predicted by the linear contrast $(b=.22, S E=.07$, $t=3.13, p<.01)$ : symbolic threat was significantly smaller in the humanized condition $(M=3.30, S D=0.56)$ than in the infrahumanized one $(M=3.74, S D=0.47)$. The quadratic effect is not significant. $^{3}$ In the third step, when the perception of threat is added to the estimated model in the first step, the multiple regression coefficient is significant, $R=.44, R_{\text {Adjusted }}^{2}=.17$, $F(3,101)=8.09, p<.001$. Furthermore, the increment in the explained variance of opposition to Turkey is also significant, $R_{\text {change }}^{2}=.13, F_{\text {change }}(1,102)=16.18, p<.001$. The greater the perception of symbolic threat, the stronger the opposition $(b=.54$, $S E=.14, t=3.94, p<.001)$. Importantly for the meditational effect, the linear contrast effect of humanity on discrimination against Turkey is no longer significant $(b=.16, S E=.10, t=1.52$, $n s$.) and the quadratic effect is still not significant. In summary, the results of the three steps indicate that the degree of humanity influenced the participants' opposition to Turkey's and that this effect is mediated by the perception of symbolic threat (see Fig. 1). The Sobel Test is significant $(z=2.44, p<.05){ }^{4}$

\footnotetext{
2 Simple effects show that discrimination against Turkey in the humanized condition is significantly smaller than in the control one, $F(1,102)=4.13, p<.05$, and that the infra-humanization condition did not differ from the control one, $F(1,102)=0.37$, ns. Importantly, ANCOVA results show that the effect of the humanity manipulation on opposition to Turkey remains significant, $F(2,101)=3.55, p<.05, \eta^{2}=.07$, after controlling for the effect of the perception of similarity-differences, which is not significant, $F(1,101)=1.24$, $n s$.

3 Simple effects show that symbolic threat is significantly smaller in the humanized condition than in the control one $(M=3.65, S D=0.73), F(1,102)=6.05, p<.05$, and that infra-humanization condition did not differ from the control one, $F(1,102)=0.45$, $n s$. Also, the effect of the humanity manipulation on symbolic threat remains significant, $F(2,101)=5.06, p<.01, \eta^{2}=.09$, after controlling for the effect of the perception of similarity-differences, $F(1,101)=3.08, p=.08, \eta^{2}=.03$.

${ }^{4}$ An additional analysis was carried out involving the manipulation of infrahumanization, the perception of threat and discrimination against Turkey. To the estimated regression model in step two, we added discrimination as an independent variable. The results show that the linear contrast effect of infra-humanization on this perception remains significant $(b=.15, S E=.07, \beta=.20, t=2.23, p<.05)$, even when the effect of opposition to Turkey is added $(b=.25, S E=.06, \beta=.37, t=3.94, p<.001)$, $R=.46$, Adjusted $R^{2}=.19, F(3,101)=9.32, p<.001$. These results reinforce our argument that symbolic threat is more likely to follow infra-humanization and to precede discrimination.
} 


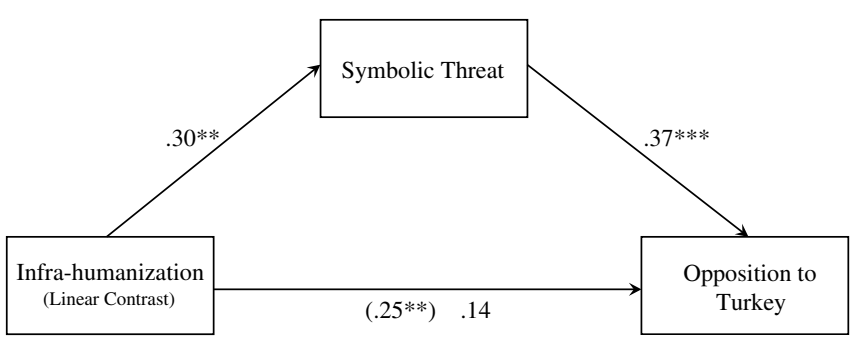

Fig. 1. Effect of the manipulation of degree of humanity on opposition to Turkish adhesion to the European Union, mediated by the perception of symbolic threat. ${ }^{* *} p<.01 ;{ }^{* * *} p<.001$.

\section{Discussion}

As predicted, the manipulation of emotional vocabulary affected the degree of humanity attributed to Turkish people, and this degree influenced the perception of symbolic threat and the opposition to Turkey's admission in the EU. From a pragmatic point of view, it is interesting to note that, despite the persistence of perceived differences, it is possible to humanize an outgroup and, consequently, to make it less susceptible to discriminatory behaviors.

The manipulation of infra-humanization of Turkey had no effect on other countries, and on the perceived difference between Turkey and EU countries. It may be that differences of habits, religion, and human rights influenced the score of the participants more than similarity in terms of emotional vocabulary. This latter finding reinforces the idea that infra-humanization, and not dissimilarity (Clement \& Krueger, 1998), is responsible for the effects found. This result indicates that the manipulation varied the similarity only on a specific aspect: the perception of humanity. Note that in all experimental conditions Turkey is perceived as equally different from the other EU countries.

Of greater importance for our theoretical model is the fact that the link between infra-humanization and discrimination is mediated by the perception of symbolic threat. Perception of threat is most likely a mechanism through which infra-humanization results in stronger opposition to Turkish entry in the EU. According to our theoretical argument, the perception of symbolic threat works as a justification for not accepting Turkey in the EU. The following study discussed here verifies the necessity of this justification in a normative context.

\section{Study 2}

The second study replicates the first one and expands it by verifying whether perceived threat elicited by infra-humanization is necessarily linked to discrimination, or whether this association depends on contexts that focus on egalitarianism or on meritocracy. In accordance with Myrdal's (1944) "American Dilemma", Katz and Hass (1988) reasoned that many White US citizens endorse alternatively feelings of friendliness and of rejection towards Blacks because they are caught in the conflicting choice between the value that everyone has equal rights and the value that everyone deserves what happens to him/her (Lerner, 1980). They suggested that people react as a function of the value that is salient in the context. When primed with meritocratic values, their participants increased their Anti-Black racial attitudes without modifying their Pro-Black attitudes. By contrast, priming egalitarian values enhanced Pro-Black racial attitudes without alteration of the Anti-Black ones.

Research on aversive racism (Dovidio \& Gaertner, 2004) has also convincingly illustrated that people who sincerely believe they are non-racists can enact discriminatory behaviors. In fact, these believers in their own egalitarianism live in Myrdal's dilemma, and contextual cues suffice to make them behave in a discriminatory way. A logical derivation is that, for aversive racists, justifications may be a mediating factor in the relationship between derogatory attitude and discrimination. When the context is permissive and defends the status quo, such as in the case of meritocracy, there may be no need for justification. What is specific to Study 2 is that perceived threat may mediate the link between infra-humanization and discrimination in an egalitarian context, while the same threat is simply the result of infra-humanization in a meritocratic context.

\section{Method}

\section{Participants}

Eighty university Portuguese students aged from 18 to 26 (51\% male) took part individually in this study. Participants were randomly distributed in one of four experimental conditions corresponding to a 2 (Manipulation of humanity: humanization vs. infra-humanization) $\times 2$ (Manipulation of norms: egalitarian vs. meritocratic) design.

\section{Procedure and manipulations}

The experiment was conducted by two researchers. Infrahumanization was manipulated before norms were introduced. Perception of symbolic threat was measured before opposition to Turkey, and manipulation measures. Finally, after having been debriefed and thanked, all participants received a five euros bonus for using for photocopying university material.

\section{Manipulation of humanity}

The first researcher manipulated humanization following the same procedure used in Study 1 . The control condition was omitted due to the fact that the quadratic effect of the manipulation in Study 1 did not influence threat and admission of Turkey in the EU.

\section{Manipulation of norms}

The second researcher told participants that they were going to take part in two unrelated studies. The first task was presented as a comprehension test, and the second one was described as a study on the entrance of new countries in the EU. The supposed comprehension test corresponded to the manipulation of norms. The researcher presented participants with a booklet containing the experimental material. The first page was entitled "Text Comprehension Task", and contained a small paragraph about egalitarianism or meritocracy as well as a small questionnaire used to reinforce the salience of the norm.

In the egalitarian norm condition, participants received a short text developing its first sentence: "In current societies, characterized by the attempt to promote equality, professional relations increasingly demand that people should have the type of training that really enhances their egalitarian values, such as equality and social justice". In the meritocratic norm condition, the text elaborated: "In current societies, there is increasing demand in professional relations for people to have the type of training that highlights the values of merit, such as competence and productivity in their competitive ability". 5

After reading the text, participants had to answer a 5-item questionnaire that presented only items on egalitarianism or meritocracy and that had been adopted from Katz and Hass (1988) (i.e., "There should be equality for everyone-because we are all human beings", "People who fail at a job have usually not tried hard enough"). Answering the questionnaire was meant to reinforce the

\footnotetext{
5 The full Portuguese text may be obtained from the authors.
} 
activation of social norms. Participants' task was to choose the item that best described the content of the text.

The second page of the experimental material contained a measure of manipulation check. By "accident", its content was illegible. When participants said they could not read what was written, the researcher told them there was a printing error and he needed to print the page again in the next room. Meanwhile, he told participants they could already respond to the alleged third study (perception of symbolic threat), so as to prevent delays in the application of the different studies. After returning to the lab, the experimenter distributed the questionnaires concerning the opposition to Turkey and the manipulation checks.

\section{Symbolic threat}

The measure of symbolic threat is the one used in Study 1. Reliability was good for Turkey ( $\alpha=.76$ ), and the index varied between 1 (lowest threat) and 7 (highest threat). As in Study 1, perceived threat was also measured for Croatia $(\alpha=.69)$ and Romania $(\alpha=.70)$ but all the manipulation's effects on composite scores of the symbolic threat were non-significant for Croatia $(F s<1.0)$ and for Romania $(F s<1.44)$.

\section{Discrimination}

The measure of behavioral intentions related to the opposition to Turkish admission into the European Union was identical to the one in Study 1. An index was computed $(\alpha=.89)$ varying from 1 (lowest opposition to Turkey) to 7 (strongest opposition to Turkey). Opposition to Croatia and Romania was also measured $(\alpha=.79$ and $\alpha=.90$, respectively). No effects of manipulations on composite scores of the opposition to Croatia ( $F s<2.24)$ and Romania $(F s<2.67)$ were found.

\section{Humanity's manipulation check}

After participants had given their answers on threat perception and discrimination against Turkey, the researcher gave them the list of emotions used in Study 1. To dispel any possible suspicion on the procedure, and before distributing the list of emotions, the researcher informed participants that the objective of this phase was to know their opinions on some characteristics of countries applying to the European Union, and that other participants would respond about people of other countries. Next, the experimenter handed out the list of emotions. The participants' task was to indicate (on a scale from $1=$ not at all likely, to $7=$ very likely) the extent to which they considered it likely that Turkish people would express each of the emotions on the list.

\section{Norms' manipulation check}

To check for the meritocratic and egalitarian norms manipulation, a task was presented as an additional element of the text comprehension exercise. Specifically, participants were instructed to read a text presented as a typical example of how mathematical learning is assessed in schools. Participants were presented with two students who had attained exactly the same level of learning in mathematics. One of them (João vs. José) was slower than the other one (José vs. João) and needed extra time to solve (correctly) 10 problems. Participants were asked to allocate each student a grade, on a scale from 0 to 20 (order of names was counterbalanced). A difference score was calculated between the grade of the two children: higher scores indicated greater application of the meritocratic norm compared to the egalitarian norm.

\section{Results}

\section{Manipulation check of humanity}

A 2 (Manipulation of humanity: infra-humanization vs. humanization) $\times 2$ (Type of emotions: primary vs. secondary emotions) $\times 2$ (Valence: positive vs. negative) mixed ANOVA was run on the expression of emotions. It revealed a significant interaction between infra-humanization manipulation and type of emotions, $F(1,78)=15.25, p<.001, \eta^{2}=.14$. As expected, Turks in the infra-humanization condition were more likely to express primary emotions $(M=4.44, S D=0.73)$ than secondary ones $(M=4.13, S D=0.89), F(1,78)=8.34, p=.01$. In the humanization condition, primary emotions $(M=4.15, S D=0.65)$ were expressed less than secondary emotions $(M=4.33, \quad S D=0.54)$, $F(1,78)=6.95, p<.01$. In accordance with the infra-humanization model, valence was not involved in any significant effect. Hence, as in Study 1, one may conclude that the humanity manipulation was effective.

\section{Manipulation check of norms}

An ANOVA was carried out on the normative index with a 2 (Manipulation of norms: meritocratic vs. egalitarian) $\times 2$ (Name of the students; João vs. José) between participants design. As anticipated, the results only show a significant main effect of the manipulation of norms, $F(1,76)=7.29, p<.01$, $\eta^{2}=.09$. Participants in the meritocratic norm condition clearly applied a more meritocratic norm $(M=3.07, S D=2.98)$ than participants in the egalitarian norm condition $(M=2.09$, $S D=2.55$ ).

\section{Perceived similarity-difference}

The scores on perception of similarity-difference measures were examined using a 2 (Manipulation of humanity: humanization vs. infra-humanization) $\times 3$ (Countries: Croatia vs. Romania vs. Turkey) factorial ANOVA. The main effect of manipulation of humanity is not significant, $F(1,78)=2.42, n s$. By contrast, the main effect of country is significant, $F(2,156)=40.57, p<.001, \eta^{2}=.34$. As in Study 1, Turkey $(M=5.57, S D=0.82)$ is perceived as more different from the $\mathrm{EU}$ than Croatia $(M=4.47, S D=0.99)$, $F(1,78)=54.97, \quad p<.001, \quad \eta^{2}=.41, \quad$ and Romania $(M=4.90$, $S D=0.95), F(1,78)=31.78, p<.001, \eta^{2}=.29$. Romania is also perceived as more different than Croatia, $F(1,78)=19.95, p<.001$, $\eta^{2}=.20$. Importantly, the interaction is not significant, $F(2,156)=0.28, n s$.

\section{Moderated mediation}

In order to test the hypotheses (1) that threat perception mediates the effect of infra-humanization on opposition to integration of Turkey in the EU; (2) and that this mediation is moderated by contextual social norms, i.e., that the mediation occurs when the egalitarian norm is activated but not when the meritocratic norm is activated, a set of multiple regressions analyses were carried out (see Muller, Judd, \& Yzerbyt, 2005). Codes were attributed to the infra-humanization conditions (i.e., humanization condition $=-0.5$; infra-humanization condition $=0.5$ ) and to the norms conditions (i.e., egalitarianism condition $=-0.5$; meritocratic condition $=0.5$ ). The scores of the perception of symbolic threat were standardized so that the mean is 0 and the standard deviation is 1.00. Next, the interaction terms were created, by multiplying the manipulation of infra-humanization by the manipulation of norms (infra-humanization $\times$ norms) and the norms by symbolic threat (norms $\times$ symbolic threat). Analyses were carried out in three steps. In the first step, opposition to Turkey was regressed on the manipulation of norms, infra-humanization, and the interaction term (infra-humanization $\times$ norms). In the second step, symbolic threat was regressed on the manipulation of norms, infra-humanization and the interaction term (infra-humanization $\times$ norms). In the third step, opposition to Turkey was regressed on the manipulation of norms, infra-humanization, the interaction term (infra-humanization $\times$ norms), symbolic threat and the interaction between norms and symbolic threat 
Table 1

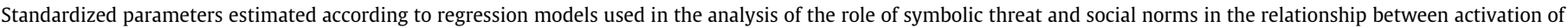
infrahumanization and opposition to Turkish adhesion to the EU

\begin{tabular}{|c|c|c|c|}
\hline \multirow[b]{2}{*}{ Predictors } & \multicolumn{3}{|c|}{$\begin{array}{c}\text { Criterion variables } \\
\beta\end{array}$} \\
\hline & Step 1: opposition to Turkey & Step 2: symbolic threat & Step 3: opposition to Turkey \\
\hline Infra-humanization (IH) & $.22^{*}$ & $.27^{* *}$ & .06 \\
\hline Norms $(N)$ & $.19^{\dagger}$ & .07 & .16 \\
\hline $\mathrm{IH} \times N$ & .08 & $-.22^{*}$ & $.21^{*}$ \\
\hline Symbolic threat (ST) & & & $.54^{* * *}$ \\
\hline$N \times \mathrm{ST}$ & & & -.05 \\
\hline
\end{tabular}

(norms $\times$ symbolic threat). ${ }^{6}$ The standardized parameters estimated are shown in Table 1.

The results of the first step show that the multiple regression coefficient is substantial and marginally different from zero, $R=.30, R^{2}$ Adjusted $=.06, F(3,76)=2.56, p<.06$. As predicted, the main effect of infra-humanization is significantly different from zero $(b=.61$, $S E=.30, t=2.00, p<.05)$ : the opposition to Turkish adhesion is significantly smaller in the humanized condition $(M=3.22, S D=1.54)$ than in the infra-humanized one $(M=3.83, S D=1.16)$. The main effect of the norms is marginally significant $(b=.54, S E=.30, t=1.77$, $p<.08)$ : opposition to Turkey was higher in the meritocratic norm condition $(M=3.80, S D=1.57)$ than in the egalitarian one $(M=3.26$, $S D=1.15)$. Those effects were not qualified by the interaction between infra-humanization and norms ( $b=.45, S E=.61, t=.74, n s$.).

The results of the second step indicate that the multiple regression coefficient is also different from zero, $R=.35, R^{2}$ Adjusted $=.09$, $F(3,76)=3.62, p<.05$. The estimated parameters analysis indicated that the main effect of norms is not significant $(b=.02, S E=.11$, $t=0.15, n s$.). However, the main effect of infra-humanization is significant $(b=.54, S E=.21, t=2.53, p<.01)$. As predicted, symbolic threat was significantly smaller in the humanized condition $(M=-.27, S D=1.02)$ than in the infra-humanized one $(M=.27$, $S D=0.90)$. This effect was qualified by the interaction between infra-humanization and norms $(b=-.86, S E=.43, t=-2.01, p<.05)$. The decomposition of this effect shows that, when the egalitarian norm was activated, the effect of infra-humanization was significant $(b=.96, S E=.30, t=3.21, p<.01)$ : symbolic threat is higher in the infra-humanization condition $(M=.44, S D=.86)$ than in the humanization one $(M=-.55, S D=0.92)$. When the meritocratic norm was salient, the effect of infra-humanization on threat was not significant $(b=.11, S E=.30, t=.37, n s$. $)$.

The results of the third step show that the multiple regression coefficient is significant and strong, $R=.59, R_{\text {Adjusted }}^{2}=.31$, $F(5,74)=7.95, p<.001$. The analysis of the parameters estimated shows that the main effect of the norms is not significant $(b=.43$, $S E=.26, t=1.67, n s$. ). Following the mediation hypothesis, the main effect of infra-humanization on discrimination is no longer significant $(b=.17, S E=.28, t=.59, n s$.). As expected, the main effect of the perception of threat is significant $(b=.76, S E=.14, t=5.41$, $p<.001$ ), so that a higher perception of threat means stronger opposition to Turkey. This effect was not qualified by the interaction between norms and the perception of threat, $(b=-.14, S E=.28$, $t=-.48, n s$.). These results indicate that, overall, the perception of threat mediates the link between prejudice and Turkey (Sobel Test, $z=2.29, p<.05)$; a higher activation of infra-humanization means

\footnotetext{
${ }^{6}$ Preliminary ANCOVA results showed that all the main and interaction effects involving symbolic threat and opposition to Turkey remained unchanged after controlling for perception of similarity-difference effects $(F<1)$. Therefore, we dropped this variable from the design.
}

a higher perception of symbolic threat which, in turn, means stronger opposition to Turkey.

Furthermore, the effect of the interaction between infrahumanization and norms, which was not significant in the first step, turns out to be significantly different from zero in the third step $(b=1.78, S E=.56, t=2.11, p<.05)$. This means that, when threat perception is controlled, the effect of infra-humanization on discrimination against Turkey was significant when the meritocratic norm was activated $(b=.75, S E=.37, t=2.05, p<.05)$, and this effect was absent when the egalitarian norm was salient $(b=-.42, S E=.42, t=-1.00, n s$.). In other words, when the effect of the perception of symbolic threat is taken into account in the model, the activation of infra-humanization continues to influence opposition to Turkey, but only when the meritocratic norm is activated. This result shows the possibility of the relationship between infra-humanization and opposition to Turkey's adhesion to the EU to be mediated by symbolic threat in the egalitarian norm condition and not in meritocratic norm condition.

In order to better interpret those results, the decomposition of the estimated parameters was carried out for each of the normative conditions, in accordance with our hypotheses for the mediation effects (see Fig. 2). As can be seen, when the egalitarian norm was salient, the influence of infra-humanization on opposition to Turkey was mediated by the perception of symbolic threat (Sobel Test, $z=2.43$, $p<.05)$, meaning that the manipulation of infra-humanization significantly predicts the perception of symbolic threat, which, in turn, predicts opposition to Turkey. A different process occurred under the meritocratic norm condition. In this condition there was no significant relationship between infra-humanization and the perception of threat, but the infra-humanization significantly influenced the opposition to Turkey. In this latter case, the manipulation of infrahumanization continued to have a strong influence on opposition to Turkey, even after the effect of symbolic threat was controlled. ${ }^{7}$

\section{Discussion}

These findings nicely complement those of Study 1. Infrahumanization induces symbolic threat and discrimination. The

\footnotetext{
${ }^{7}$ We carried out an additional analysis involving the manipulation of infrahumanization, the manipulation of norms, the perception of threat and opposition to Turkey. We added to the estimated regression model in the second step, as predictive variables, opposition to Turkey and the terms of interaction between this opposition and the manipulation of norms. The results show that the effect of infra-humanization on the symbolic threat is still marginally significant $(b=0.32, S E=0.19, \beta=.16$ $t=1.72, p=.09)$, while the effects of the norms $(b=-.08, S E=.19, \beta=-.04, t=-0.44$, $n s$.) are not. Moreover, the terms of interaction (norms $\times$ infra-humanization) remained significant $(b=-.92, S E=0.37, \beta=-.23, t=-2.48, p<.05)$, even when the main effects of opposition to Turkey $(b=0.56, S E=0.10, \beta=.58, t=5.99, p<.001)$ and the interaction between opposition to Turkey and the norms $(b=-.26, S E=.20$ $\beta=-13, t=-1.32, n s$.), were taken into account. As in Experiment 1, these results reinforce our argument that symbolic threat follows infra-humanization and precedes discrimination.
} 


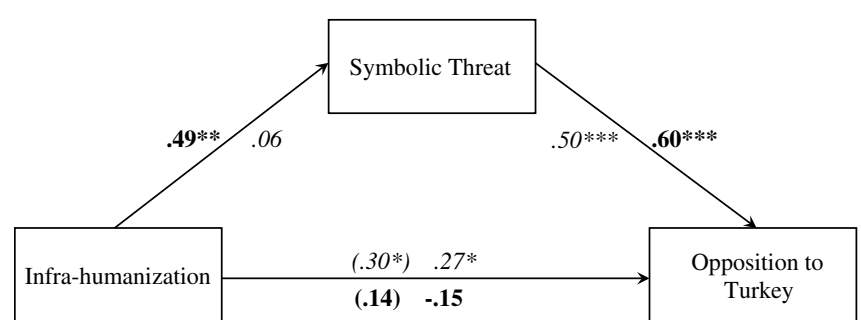

Fig. 2. Effects of the manipulation of degree of humanity on opposition to Turkey, mediated by the perception of symbolic threat and moderated by social norms $p<.05 ;{ }^{* *} p<.01 ;{ }^{* * *} p<.001$.

originality of the present study is that it shows the effect of normative context upon the role of threat in the triad infra-humanization, threat, and discrimination. When the normative context values egalitarianism, participants experience a dilemma (Dovidio \& Gaertner, 2004), and they use symbolic threat as a justification for discrimination. The dilemma is absent when the norms are permissive (meritocratic). In such a context, no justification is needed to discriminate. In other words, the mediation of threat between infra-humanization and discrimination is moderated by the normative context.

\section{General discussion}

The present two studies contain three original findings. While infra-humanization has mainly dealt with natural groups (but see Demoulin et al., in press), it is the first time that a manipulation is shown to affect the humanization of a disliked outgroup. Second, this manipulation has consequences upon discrimination, and the link between the two is mediated by perceived threat. Third, infra-humanization elicits symbolic threat and this threat plays the role of justification for discrimination in an egalitarian context that discourages essential differences between groups.

Infra-humanization can thus be manipulated and it has consequences. Opposition to the Turkish outgroup was less intense in the humanized condition than in the infra-humanized one. Our second prediction concerning perception of threat was supported. Infra-humanization induces threat. Threat perception is, nowadays, a fundamental concept in understanding the genesis of infra-humanization and discrimination (Leyens et al., 2007). Both the integrated threat theory (Stephan \& Stephan, 2000) and the unified instrumental model of group conflict (Esses, Jackson, Dovidio, \& Hodson, 2005) propose a link between threat, negative attitudes, and discrimination. For these authors, however, threat can take two forms, realistic and symbolic. Infra-humanization concerns only one aspect of threat. Outgroups are infra-humanized because they are essentially different in terms of identity (Leyens \& Demoulin, in press). These differences constitute a danger, not at a material level but at a symbolic one.

Because symbolic threat may constitute a danger, it can justify rejection of the outgroup, or maintain it outside the ring of its allied countries. These results are in accordance with several lines of thinking (Crandall \& Eshleman, 2003) and research (Dovidio \& Gaertner, 2004; Sidanius \& Pratto, 1999). To the same extent that people may infra-humanize a group that they have previously attacked in order to prevent guilt (Zebel et al., 2008; see also Castano \& Giner-Sorolla, 2006), they may attack the group because, supposedly, this group represents a threat that justifies the attack.

More original than mediation per se is the fact that this mediation is moderated by normative contexts, as verified in Study 2 Perceived symbolic threat is not necessarily a mediator. Normative contexts can facilitate a direct effect upon discrimination (Katz \& Hass, 1988; Vala, Lima, Pereira, \& Leyens, submitted for publication). In Study 2, the egalitarian and meritocratic norms were barely suggested to participants and their effect upon the rejection or acceptance of Turkey just failed to reach the conventional level of significance. They had, however, a significant effect upon the mediation. As seen earlier, Turkey is a country disliked by many people and it is rejected because of the threat it represents. When the norm is to behave as a function of perceived deservingness and established social hierarchy, one may discriminate a disliked outgroup and does not need justification for rejection. The case is completely different when people are made aware of essential equality between groups. Lack of humanity and dislike are still there but they need the help of a justification to translate these perceptions into discrimination. The originality of Study 2 lies in the way it shows how the mediation of threat is moderated by norms.

In summary, infra-humanization elicits both perceived symbolic threat and discrimination. However, depending on the normative context, permissive or not, threat represents a danger or an excuse for ill-intentioned behaviors. Finally, what is remarkable in the two studies is that the degree of humanity was manipulated by the frequency of emotional words. Nevertheless, Turkey was rated equally different from the other European countries in all conditions; participants had probably in mind differences in religion, and culture. Despite the unanimity about these differences, humanizing Turkey sufficed to reduce the threat and the opposition. It should also be noted that the manipulation of Turkey did not generalize to other countries. In these other countries, threat and opposition remained equal, independently of the status of Turkey. This absence of generalization reinforces the idea that groups often constitute walls of differences (Leyens et al., 2007).

\section{Implications and limitations}

The present set of studies brings optimistic and more pessimistic perspectives on harmony between groups. The clear optimistic message is that even groups with a bad reputation, like Turkey for most European countries, can be humanized. To achieve full humanity, these outgroups have to show that they share core similarities (i.e., emotional vocabulary) with the ingroup. The problem is that the proof cannot come from outgroups themselves (e.g., Vaes et al., 2003), but has to be delivered by neutral third parties. Nevertheless, the possibility of humanizing a disliked outgroup is a great step towards harmony between groups.

Maybe paradoxically, the more pessimistic message comes from the role of norms. On the one hand, insisting upon egalitarian norms has only a slight effect upon discrimination, but it may be that its induction was too weak. One would have hoped that the impact of egalitarian norm would have been greater. On the other hand, when looking at the interaction between norms and humanity and its effect upon symbolic threat, the results should raise vigilance. In the case of meritocratic norms, this threat is high and does not vary with humanization. In the case of egalitarian norms, discrimination and threat should be lower but, because infra-humanization elicits threat, discrimination is legitimized. Thus, even if the normative context can affect discrimination against an infra-humanized group, stigmatization will remain because the norm is permissive or because the context provides excuses.

Limitations of the current research may derive from the operationalization of some theoretical variables. Discrimination is often defined as a behavioral measure (Leyens, Yzerbyt, \& Schadron, 1994). However, it is often operationalized as a behavioral intention (e.g., Schutz \& Six, 1996; Sellers \& Shelton, 2003). It was the case in the present study. The intentions were not aimed at specific targets. Given the general frame of the research, opposition to Turkey related to impersonal action tendencies in order to help or prevent Turkey joining EU. 
In their meta-analysis, Schutz and Six (1996) found a higher correlation between negative attitudes and behavioral intentions $(r=.45, p<.001)$ than between prejudiced attitudes and discriminatory behaviors $(r=.36, p<.001)$. This gap calls for attempts to measure discriminatory behaviors rather than intentions. Behaviors will most likely be less pronounced than intentions, but we do not expect the process highlighted in the present studies would change (Katz, Wackenhut, \& Hass, 1986). Behaviors, rather than intentions, would simply add ecological validity.

In spite of these potential limitations, we believe in the importance of the take-home message captured in the French saying: "Excuses are made to be used." When discrimination against a disliked group is not legitimated by a permissive context, people may find justifications in perception of threat. Metaphorically, people are like the wolf in La Fontaine's (1668) fable that invokes any reason to attack the sheep drinking from the same river. On a more religious tone, "all the ways of a man (sic) are clean in his own sight; but the Lord weighs the motives" (Pv. 16:2).

\section{Acknowledgments}

The authors thank Vincent Yzerbyt for his comments and assistance with the data analysis. We also thank Nicole Shelton and three anonymous reviewer for their helpful comments. We are grateful to Joana Alexandre, Patrícia Duarte, and Susana Marques for their excellent help in conducting the studies.

\section{References}

Baron, R. M., \& Kenny, D. A. (1986). The moderator-mediator variable distinction in social psychological research: Conceptual, strategic, and statistical considerations. Journal of Personality and Social Psychology, 51, 1173-1182.

Biernat, M., Vescio, T. K., \& Theno, S. A. (1996). Violating American values: A "value congruence" approach to understanding outgroup attitudes. Journal of Experimental Social Psychology, 32, 387-410.

Boccato, G., Cortes, B., Demoulin, S., \& Leyens, J.-P. (2007). The automaticity of infrahumanization. European Journal of Social Psychology, 37, 987-999.

Castano, E., \& Giner-Sorolla, R. (2006). Not quite human: Infrahumanization in response to collective responsibility for intergroup killing. Journal of Personality and Social Psychology, 90, 804-818.

Cialdini, R. B., Kallgren, C. A., \& Reno, R. R. (1991). A focus theory of normative conduct: A theoretical refinement and reevaluation of the role of norms in human behavior. In M. P. Zanna (Ed.). Advances in experimental social psychology (Vol. 24, pp. 201-234). San Diego: Academic Press.

Cialdini, R. B., \& Trost, M. R. (1998). Social influence: Social norms, conformity, and compliance (4th ed.. In D. T. Gilbert, S. T. Fiske, \& G. Lindzey (Eds.). The handbook of social psychology (Vol. 2, pp. 151-192). Boston: McGraw-Hill.

Clement, R. W., \& Krueger, J. (1998). Liking persons versus liking groups: A dualprocess hypothesis. European Journal of Social Psychology, 28, 457-469.

Cortes, B., Demoulin, S., Rodriguez-Torres, R., Rodriguez-Perez, A., \& Leyens, J.-P. (2005). Infra-humanization or familiarity? Attribution of uniquely human emotions to the self, the ingroup, and the outgroup. Personality and Social Psychology Bulletin, 31, 243-253.

Crandall, C. S., \& Eshleman, A. (2003). A justification-suppression model of the expression and experience of prejudice. Psychological Bulletin, 129, 414-446.

Cuddy, A. J. C., Rock, M., \& Norton, M. I. (2007). Aid in the aftermath of Hurricane Katrina: Inferences of secondary emotions and intergroup helping. Group Processes E' Intergroup Relations, 10, 107-118.

Demoulin, S., Cortes, B. P., Viki, T. G., Rodriguez, A. P. Rodriguez, R. T,. Paldino, M. P., et al. (in press). The role of ingroup identification in infra-humanization. International Journal of Psychology.

Demoulin, S., Leyens, J.-P., Paladino, M. P., Rodriguez-Torres, R., Rodriguez-Perez, A., \& Dovidio, J. F. (2004). Dimensions of "uniquely" and "non-uniquely" human emotions. Cognition and Emotion, 18, 71-96.

Dovidio, J. F., \& Gaertner, S. L. (1986). Prejudice, discrimination, and racism. Orlando: Academic Press.

Dovidio, J. F., \& Gaertner, S. L. (2004). Aversive racism. In M. P. Zanna (Ed.). Advances in experimental social psychology (Vol. 36, pp. 1-51). San Diego, CA: Academic Press.

Esses, V. M., Jackson, L. M., Dovidio, J. F., \& Hodson, G. (2005). Instrumental relations among groups: Group competition, conflict, and prejudice. In J. F. Dovidio, P. Glick, \& L. A. Rudman (Eds.), On the nature of prejudice: Fifty years after Allport (pp. 227-243). Malden: Blackwell.

Eurobarometer (2006). European social reality (Standard Eurobarometer No. 64): European Commission.

Gaertner, S. L., \& Dovidio, J. F. (2000). Reducing intergroup bias: The common ingroup identity model. Philadelphia, PA: The Psychology Press.
Haslam, N. (2006). Dehumanization: An integrative review. Personality and Social Psychology Review, 10, 252-264.

Katz, I., \& Hass, R. G. (1988). Racial ambivalence and American value conflict: Correlational and priming studies of dual cognitive structures. Journal of Personality and Social Psychology, 55, 893-905.

Katz, I., Wackenhut, J., \& Hass, R. G. (1986). Racial ambivalence, value duality, and behavior. In J. F. Dovidio \& S. L. Gaertner (Eds.), Prejudice, discrimination and racism (pp. 35-59). San Diego: Academic Press.

La Fontaine, J. (1668/2004). The fables of La Fontaine. Whitefish, MT: Kessinger Publishing.

Lerner, M. J. (1980). The belief in a just world: A fundamental delusion. New York Plenum Press.

Leyens, J.-P., \& Demoulin, S. (in press). Hierarchy-based groups: Real inequalities and essential differences. In S. Otten, T. Kessler, \& S. Sassenberg (Eds.), Intergroup relations. The role of motivation and emotion. Oxford: Psychology Press.

Leyens, J.-P., Cortes, B., Demoulin, S., Dovidio, J. F., Fiske, S. T., Gaunt, R., et al. (2003) Emotional prejudice, essentialism, and nationalism: The 2002 Tajfel Lecture European Journal of Social Psychology, 33, 703-717.

Leyens, J.-P., Demoulin, S., Vaes, J., Gaunt, R., \& Paladino, P. M. (2007). Infrahumanization: The wall of group differences. Social Issues and Policy Review, 1 139-172.

Leyens, J.-P., Paladino, P. M., Rodriguez-Torres, R., Vaes, J., Demoulin, S., RodriguezPerez, A., et al. (2000). The emotional side of prejudice: The attribution of secondary emotions to ingroups and outgroups. Personality and Social Psychology Review, 4, 186-197.

Leyens, J.-P., Rodriguez-Perez, A., Rodriguez-Torres, R., Gaunt, R., Paladino, M.-P. Vaes, J., et al. (2001). Psychological essentialism and the differential attribution of uniquely human emotions to ingroups and outgroups. European Journal of Social Psychology, 31, 395-411.

Leyens, J.-P., Yzerbyt, V., \& Schadron, G. (1994). Stereotypes and social cognition. London: Sage.

Moskowitz, G. B., Gollwitzer, P. M., Wasel, W., \& Schaal, B. (1999). Preconscious control of stereotype activation through chronic egalitarian goals. Journal of Personality and Social Psychology, 77, 167-184.

Moskowitz, G. B., Salomon, A. R., \& Taylor, C. M. (2000). Pre-consciously controlling stereotyping: Implicitly activated egalitarian goals prevent the activation of stereotypes. Social Cognition, 18, 151-177.

Muller, D., Judd, C. M., \& Yzerbyt, V. Y. (2005). When moderation is mediated and mediation is moderated. Journal of Personality and Social Psychology, 89, 852-863.

Myrdal, G. (1944). An American dilemma: The negro problem and modern democracy. New York: Harper and Row.

Paladino, M. P., Leyens, J.-P., Rodriguez-Torres, R., Rodriguez-Perez, A., Gaunt, R., \& Demoulin, S. (2002). Differential association of uniquely and non uniquely human emotions with the ingroup and the outgroup. Group Processes $\mathcal{E}$ Intergroup Relations, 5, 105-117.

Pettigrew, T. F. (1958). Personality and social-cultural factors in intergroup attitudes: A cross-national comparison. The Journal of Conflict Resolution, 2, 29-42.

Saucier, D. A., Miller, C. T., \& Doucet, N. (2005). Differences in helping whites and blacks: A meta-analysis. Personality and Social Psychology Review, 9, 2-16.

Schutz, H., \& Six, B. (1996). How strong is the relationship between prejudice and discrimination? A meta-analytic answer. International Journal of Intercultural Relations, 20, 441-462.

Sellers, R. M., \& Shelton, J. N. (2003). The role of racial identity in perceived racial discrimination. Journal of Personality and Social Psychology, 84, 1079-1092.

Sidanius, J., \& Pratto, F. (1999). Social dominance. New York: Cambridge University Press.

Stephan, W. G., \& Stephan, C. W. (2000). An integrated threat theory of prejudice. In S. Oskamp (Ed.), Differential association of uniquely and non uniquely human emotions with the ingroup and the outgroup. NJ: Lawrence Erlbaum Associates.

Tam, T., Hewstone, M., Cairns, E., Tausch, N., Maio, G. R., \& Kenworthy, J. (2007). The impact of intergroup emotions on forgiveness in Northern Ireland. Group Processes E' Intergroup Relations, 10, 119-136.

Vaes, J., Paladino, M. P., Castelli, L., Leyens, J.-P., \& Giovanazzi, A. (2003). On the behavioral consequences of infrahumanization: The implicit role of uniquely human emotions in intergroup relations. Journal of Personality and Social Psychology, 85, 1016-1034.

Vala, J., Lima, M. E., Pereira, C., \& Leyens, J.-P. (submitted for publication). Depersonalisation, normative contexts and discrimination of Black people.

Vala, J., Lima, M. E., \& Lopes, D. (2004). Social values, prejudice and solidarity in the European Union. In W. Arts \& L. Halman (Eds.), European values at the end of the millennium (pp. 139-163). Leiden: Brill.

Viki, G. T., Gratien, M., Eller, A., Alys, L. \& Pina, A. (submitted for publication). Perceived threat and the differential attribution of uniquely human emotions to the ingroup and outgroup.

Viki, G. T., Zimmermann, A., \& Ballantyne, N. (submitted for publication). Dehumanization and attitudes towards the ill-treatment and social exclusion of Muslims: The mediating role of perceived symbolic threat.

Zebel, S., Zimmermann, A., Viki, G. T., \& Doosje, B. (2008). Dehumanization and guilt as distinct but related predictors of support for reparation policies. Political Psychology, 29, 193-220.

Zimmermann, A, Doosje, B, Zebel, S. \& Viki, G. T. (submitted for publication). Dehumanization and moral responsibility as predictors of outgroup-focused outcomes and support for terror threat prevention. 